\title{
Scope of Action from a Scandinavian (Nordic) Angle
}

\author{
Niklas Bruun
}

I. Laval and Viking

$\begin{array}{ll}\text { II. Rüffert } & 114\end{array}$

III. Conclusion: ILO 94 and the Rüffert case 116

My understanding is that I am expected to discuss the new case-law from the ECJ (Laval C-341/05, Viking C-438/05 and Rüffert C-346/06) and the problems they pose for the labour market system in the Scandinavian countries.

I take it for granted that the main content of these cases are known by the audience, I therefore go straight on and discuss what we should do about this and what problems we face from a Scandinavian point of view and even on a more general level.

\section{Laval and Viking}

These judgments deal with a peace-obligation for transnational industrial action that has an impact on one of the four EC freedoms (free movement for goods, labour, services and capital).

The judgments do have a clear impact on Scandinavian law. This impact is partly common for all the Scandinavian or even Nordic countries. The impact of the Vikingjudgment restricting collective action in situations of crossborder establishment is clearly similar for all Nordic countries and will certainly have implications on how trade unions and their international organisations take use of industrial action in such situations. The Laval-judgment again will clearly bring about changes to the law in force in these countries. In this respect there are however also several different features in the situation of the respective states: Sweden has a special situation with its unique Lex Britannia that has to be dealt with since the ECJ declared that it is not compatible with EC law. Finland, Denmark and Norway have ratified ILO Convention 94 on Social Clauses in Public Contracts (public procurement). Sweden has not ratified that Conven- 
tion. Finland has a well established system for making collective agreements binding "erga omnes", which makes the situation regarding the implementation of the Posting of Workers Directive (96/71/EC) less problematic for Finland.

For both Denmark and Sweden the national Acts on Posting of workers must be amended as least regarding minimum wages. There is in the author's view no need to change the system fundamentally, but the question is how the new legislation can build upon the national branch level collective agreements (covering a vast majority of the workers in the sector) and at the same time fulfil the EC requirements concerning coverage, non discrimination and transparency? If the social parties cannot solve the issue of minimum wages in collective agreements, there is in the end no other solution than legislated minimum wages.

The necessary legislative amendments are in a preparatory stage both in Denmark and Sweden. In both countries tripartite bodies have been appointed to prepare for amendments in legislation and collective agreements. In Denmark this tripartite body presented its proposals on 19 June 2008 and the responsible Minister Claus Hjort Fredriksen has declared that the Danish government will take action accordingly. The tripartite body suggests an amendment to the Danish Act on posting of workers which explicitly would state that industrial action can be undertaken against foreign service providers in the same way as action can be taken against Danish ones. An explicit new condition for such industrial action is that the representative national collective agreement applicable in the branch contains clear stipulations on the minimum wages that a foreign service provider has to pay. This again creates a responsibility for the social partners to amend the collective agreements accordingly.

In Sweden the preparation of legal measures to be undertaken is still in a preparatory phase and it is not self-evident what solutions will be proposed.

\section{Rüffert}

In the Rüffert case a company, Objekt und Bauregie, was awarded a public contract. The company employed as a subcontractor another undertaking established in Poland. In summer 2004 this undertaking came under suspicion of having employed workers on the building site at a wage below that provided for in the 'Buildings and public works' collective agreement. ${ }^{1}$ Following investigation, Land Niedersachsen terminated the con-

1 Paragraph 3(1) of the Landesvergabegesetz, headed 'Declaration that the collective agreement will be complied with' states:

"Contracts for building services shall be awarded only to undertakings which, when lodging a tender, undertake in writing to pay their employees, when performing those services, at least the remuneration prescribed by the collective agreement at the place where those services are performed and at the time prescribed by the collective agreement. For the purposes of the first sentence, the term 
tract with Objekt und Bauregie based on the fact, inter alia, that Objekt und Bauregie had failed to fulfil its contractual obligation to comply with the wage provision in a collective agreement which it was bound to by law. A penalty notice was issued against the person primarily responsible at the undertaking established in Poland, accusing him of paying 53 workers engaged on the building site only $46.57 \%$ of the prescribed minimum wage.

The issue went at first instance to the regional court in Hannover and then to the higher regional court, which stayed the proceedings and referred the following question to the European Court of Justice (ECJ):

"Does it amount to an unjustified restriction on the freedom to provide services under the EC Treaty if a public contracting authority is required by statute to award contracts for building services only to undertakings which, when lodging a tender, undertake in writing to pay their employees, when performing those services, at least the remuneration prescribed by the collective agreement in force at the place where those services are performed?"

The ECJ read the Posting of Workers' Directive 96/71/EC 2 in the light of Article 49 EC. The ECJ held that the German federal legislation did not satisfy the conditions regarding minimum wages in the host country which are binding on a service provider as regards payment of posted workers. According to the court, the legislation did not declare collective agreements generally applicable, and applied only to a part of the sector (public contracts), although in fact it did also apply to the main part of the private sector. Nor did the legislation satisfy the criteria laid down in Article 3(8) of the Directive. The ECJ gave a very restrictive interpretation of Article 3(7) of the Directive, which states that paragraphs 1 to 6 shall not prevent application of terms and conditions of employment which are more favourable to workers. In sum, the Court came to the conclusion that a Member State is not entitled to impose such legislation on contractors. Directive 96/71, interpreted in the light of Article 49 EC, precludes a Member State from adopting legislation such as that in force in Land Niedersachsen.

The ECJ judgment is in many ways problematic from a legal point of view. Here I do not present any general critique of the conclusions in the Rüffert case and only discuss some issues related to ILO 94. It has, however, to be stated that in Rüffert, contrary to what was argued to be the case in the Laval judgment ${ }^{3}$, the wage level was transparent and easy to ascertain in advance. It is also clear that the legislation is valid on national level and binds German companies that take part in a public procurement procedure in

'services' means services provided by the principal contractor and by subcontractors. The first sentence shall also apply to the award of transport services in local public transport."

2 Directive 96/71/EC concerning the posting of workers in the framework of the provision of services. OJ 1996, L18/1.

3 Case C-341/05, Laval un Partneri Ltd v Svenska Byggnadsarbetareförbundet, Svenska Byggnadsarbetareförbundet, avd. 1, Svenska Elektrikerförbundet, Opinion of Advocate General Paolo Mengoz$z i, 23$ May 2007, ECJ decision, 18 December 2007. 
Land Niedersachsen. The Rüffert judgment is, in my view, the first where the ECJ no longer requires that competition be on equal terms between national and foreign service providers. Rather, the Court takes the position that foreign service providers are to be allowed a competitive advantage by paying lower wages, contrary to what is provided by the federal law referring to the wage level in the sectoral collective agreement.

\section{Conclusion: ILO 94 and the Rüffert case}

The federal legislation in Land Niedersachsen complies precisely with the obligation imposed by ILO Convention 94 on those states that have ratified it. Article 2 of Convention 94 states:

"Contracts to which this Convention applies shall include clauses ensuring to the workers concerned wages (including allowances), hours of work and other conditions of labour which are not less favourable than those established for work of the same character in the trade or industry concerned where the work is carried on - (a) by collective agreement...".

Germany has not ratified Convention ILO 94. However, the Convention has been ratified by a considerable number of Member States: Austria (1951), Belgium (1952), Denmark (1955), Finland (1951), France (1951), The Netherlands (1952), Italy (1952), Spain (1971) and the UK (1950, though it was denounced by the UK in 1982). Among the new Member States, at least Bulgaria (1955) and Cyprus (1960) have ratified the Convention.

In light of this, the ECJ's interpretation of the Posting Directive in the Rüffert case is remarkable. When both adopting and implementing the Posting Directive, the Commission declared that the Directive was fully consistent with ILO Convention 94. The position after Rüffert is that the legal situation will vary among Member States. Those Member States that have ratified ILO 94 before being bound by the Treaty can, according to Article $307 \mathrm{EC}$, still apply ILO 94, at least during a lengthy transitory period if it is to be denounced. From a Scandinavian angle one may ask whether this means that Finland and Denmark are in a different position than Sweden, because the latter has not ratified the Convention.

The conflict between the Rüffert judgment and ILO 94 is clear but of limited scope. It does not apply to public procurement exclusively within a Member State (where there is no cross-border posting of workers); it does not apply when posting is of workers from a non-EU Member State; and it does not apply when cross-border work is performed in the context of public procurement in forms which do not involve posting of workers.

The starting point for regulation of public procurement in the European Union has been that the Member States should be free to stipulate national standards, including for 
wage regulation, provided there is equal treatment and no discrimination whatsoever is allowed in respect of foreign serviceproviders. This starting point is fully compatible with the ILO 94.

The Rüffert case has created confusion, uncertainty and the risk of different rules applying in Member States. The conclusion is that the Posting Directive 96/71/EC, as interpreted by the ECJ in the light of Article 49, must be clarified in order to be in harmony with ILO Convention 94.

This could quite easily be done by inserting a clause into the Directive clearly stating that either the public sector (procurement) can be regarded as a separate sector within the meaning of the Directive (Article 3(8)) or that wage standards linked to or clearly defined in collective agreements in a specific sector, at national or federal level, can be considered as part of the minimum standard that foreign service providers are obliged to apply under condition that this is a general requirement under the EC Public Procurement regime.

It is important that the European Union Member States defend the freedom of all Member States to continue to adhere to ILO Convention 94 and apply the principles on equal treatment of employers that is the fundament of this instrument. 
